\title{
An Assessment Of Twitter Effectiveness On Increasing Trust In E-Commerce In Saudi Arabia
}

\author{
Fahad Ali Alqammash \\ Administrative Sciences, \\ Najran University, Saudi Arabia
}

\begin{abstract}
Social media has been widely used by businesses and integrated with E-commerce solutions in order to increase two-way interaction between customers and businesses as well as to increase transparency and trust. Twitter and Facebook are two platforms whereby businesses are able to better understand the needs and wants of the customers and as a means for customers to be able to relate better to the businesses. While previous studies have identified factors impacting trust in e-commerce, social commerce has not been considered. Given its prevalence and its use in enhancing customer perceptions about trust, this study aims to explore social media (Twitter and Facebook) adoption by small and medium scale e-businesses in the Kingdom. Using a mixed methods approach, the study analyses to what extent Twitter and Facebook participation has improved trust thereby impacting revenue. The study analyses how customers are able to better relate to the brand because of social commerce integration.
\end{abstract}

Keywords: Social Media, Saudi Arabia, E-Government, Social Commerce, Trust

\section{INTRODUCTION}

E-commerce (Electronic commerce) is the trade of goods and services with the usage of internet. E-Commerce evolution and its adoption has been studied widely in the literature. In the recent times, there is an increase in the number of Small and Medium Enterprises (SMEs) adapting to selling their products and services using the internet (Mohd, Yasin N, and Alam S. Shah, 2010)

Ecommerce becomes significant factor for many businesses to cope with the competitive markets. Across the globe, the usage of internet by people has considerably increased which facilitates the growth of small e-business practices (Chiravuri, Ananth and Nazareth, Derek., 2001)

Currently, small scale businesses are able to generate a strong web presence, thereby improving purchase and sales online. Due to the increased cases of small scale enterprises fraud, there is an issue of trust prevailing widely. While trends show an increase in the number of people having access to internet technologies, one of the impediments for e-commerce is trust. Researchers posit that people have issues trusting online entities (Gefen, David and Detmar W. Straub, 2004) ( Qu, Zhe., Wang, Youwei., Wang, Shan and Zhang, Yanhui, 2012). Trust can be defined as the willingness of an individual to be vulnerable in a transaction with the belief that the other party in the transaction will perform the expected action (Sashi, C.M.,2012)

In e-businesses, trust refers to the consumers' belief that that the products delivered by the seller would be of good quality and the payments made over the internet are valid and secure (Laroche, Michel, Habibi, Mohammad Reza., Richard, Marie-Odile and Sankaranarayanan, Ramesh, 2012) 
Trust is the major driving factor for the customer to buy products or services online. Other factors of trust include the company's reputation, the quality of information web interface design and ease of use for potential customers to purchase through the company's website. Nowadays, small scale e-businesses are channelling their marketing energies to social network marketing (Mohd, Yasin N, and Alam S. Shah., 2010) Integrating social media platform with ecommerce platforms is referred to as social commerce. Social commerce that is mediated by social media enables businesses to use these platforms effectively as a marketing tool in order to boost sales as well as overcome the trust concerns that customers have with e-commerce. Additionally, it enables businesses in enhancing its brand image, strengthening the client relationships, and improving networking between the customers and businesses. The power of social media has made it compelling for entrepreneurs to adapt social commerce which enables them add a social layer to their business thereby improving marketing and promotional activities (Nicolaou, N. and Shane, S., 2009)

Research shows that over the last 10 years, the growth of internet proliferation has seen an exponential growth of $400 \%$ in usage. A recent study conducted by Sacha Orloff Consulting group shows that internet access is available to $65.8 \%$ of the Saudi population and the ratio of mobile phones for residents of Saudi is 1.8:1, which is for every 10 individuals, 18 mobile phones are available. This study also shows that Twitter is the most used social media platform and that the residents use Twitter through their mobiles. Compared to other countries in the world, Saudi Arabia has the highest ranking for social media usage globally (Khalidi et al., 2014).

Despite there being evidence of increased proliferation of technology and advancements in the way businesses operate, there are several gaps in the literature. Firstly, evolution of social media commerce in Saudi Arabia is little known. Even those studies that show e-commerce evolution, focus either on customers or businesses separately to understand the determinants of ecommerce adoption and trust. While there are several studies that focus on e-commerce trust and social media, these studies focus only on developed nations or western economies. Finally, studies that discuss impact on trust, performance through social media integration on e-commerce either use qualitative or quantitative approaches. While these to a certain extent explain the relationship between trust and performance, they do not holistically look at showing causation between these while at the same time exploring different perspectives from varied stakeholders.

This paper will address these gaps, the main aim to review and examine the impact of social media participation and how it affects the trust in ecommerce. This study explains about the adaptation and implementation of electronic and social commerce in the Kingdom of Saudi Arabia and how this impacts the performance of SMEs. This research highlights how the social networking platforms especially Twitter and Facebook have gained acceptance over's the years and how this has helped businesses increase trust in the e-commerce arena by using a mixed methods research approach.

Keeping in mind the research objectives, the following are the central questions this research wishes to address are:

- To what extent has social media impacted consumer trust on e-commerce platforms?

- Does increased trust due to social media integration lead to increase in performance of the firm? 
This research contributes to both research and practice in several ways. Firstly, this research is one of the first papers that use both qualitative and quantitative approach to explore in detail the impact of social media adoption on trust in ecommerce. Secondly, it overcomes the gap in the empirical setting by looking at the trends in KSA. It uses the cultural dimensions of Hofstede to specifically understand the factors that impact trust in e-commerce in KSA and how this in turn impacts performance of the business. Practically it enables businesses to plan and implement e-commerce and social media strategies to enhance trust and performance.

The rest of the paper is organized as follows. The second chapter provides a critical review of related literature and also explains the theoretical framework for this research. The third chapter explains the research methods employed and a justification for the same. The fourth chapter shows the results followed by discussions and conclusions.

\section{LITERATURE REVIEW}

The technology proliferation has led to an exponential increase in how internet is now accessible to a larger population and this has in turn impacted the use of social media especially in the Middle East. 92\% of the population in the United Arab Emirates have access to the internet and social media while $97 \%$ of the population in the Middle East have access. Technology diffusion is high and this has led to businesses engaging constantly with customers, governments using social media platforms for public engagement and also by businesses to increase reputation and trust (Dennis, Martin and Wood, 2016). The literature review comprises of two sub-sections. The first subsection discusses the theoretical framework that is used in this research by understanding the cultural dimensions that drive behaviour. The second subsection provides an overview of e-commerce, trust and social commerce and also explains the determinants of trust in e-commerce given the empirical context.

\section{Theoretical Framework}

Understanding e-commerce policies and social media participation requires an understanding of the country context or the empirical setting to get a holistic idea about the socio-cultural environment where such policies have been implemented. With the population of 32 million whereby one-third of it are foreigners, it is the second largest economy with respect to oil reserves and the largest Middle-Eastern Arabian Nation (Central Department of Statistics and Information, 2010)

The culture of the country reflects Islamic beliefs and is a conservative tradition that strongly believes and encourages the institution of family which comprise not just of the immediate family of children and spouse but a larger, extended family. The pivotal aspects that drive the decision-making and attitudes of people include respect for authority, tradition as well as family (Georgas et al, 2006)

The history of internet in Saudi Arabia dates back to 1999. Most business now have a website and social media platforms are integrated to enable interaction with customers. Several services are offered by websites to ensure the level of support and interaction provided to the clients. The study conducted in 2014 by the Economist prove that more than 8 million of the population which is nearly $25 \%$ of the total population can access the social media platform such as Facebook, whereas $20 \%$ of them use Twitter. The survey also suggests that large percent of population who use social media are men aged 26-34 years (Economist, 2014)

Hofestede's model suggests six dimensions to explain the society's cultural and ethical for better understanding of the behavioral patterns of the population. By using the six dimensions, 
culture can be analysed. The first dimension that is included in the model is the Power distance Index (PDI) explains the degree to which the power distribution is accepted and how decision making are done by the powerful members is impactful. The second dimension is individualism vs. collectivism. This focuses on the extent of social ties that describes cohesiveness to see how the individuals have formed groups and how closely they are integrated with respect to loyalty, support and conflict resolution. The third criterion is about uncertainty. It discusses about attitudes on how populations try to avoid the uncertainty and the extent to which the society or the culture can tolerate ambiguity. When there are strict code of laws and a tendency for hierarchical ranking, this leads to a society where the thoughts and free flow of ideas are neglected. The fourth aspect described in the model is masculinity vs. femininity which explains to what extent, heroism, assertiveness and aggressiveness is preferred by the society. Feminine societies are said to have higher quality of life by showing utmost care for values, modesty being emphatic. The long-term orientation that affiliates how the future is connected with present and the past is the fifth aspect discussed in this framework. Low degree states a traditional environment where being loyal has the higher value. Higher degree includes the societies which are more realistic and ensures adaptable situations. The final aspects is the measure of happiness, shows at what level people are gratified, when the society is not controlling and the desires to have fun and enjoy life (Hofstede, 2001)

According to Hofstede's cultural dimension model it is evident that the Kingdom of Saudi Arabia is high in terms of power distance, masculinity, uncertainty avoidance and collectivism. This states that the inequality is in the higher side given the huge differences and gender bias. People prefer stability over ambiguity. The men are said to be on the forceful side while women are expected to be caring and nurturing. Studies show how femininity and short-term orientation is impactful in the intention of the users to consume the services indirectly (Zhang et al., 2009)

Adoption of technology has positive impacts with the attributes power distance and uncertainty avoidance. (Leidner \& Kayworth, 2006) It can also be said that given that the culture does not prefer uncertainty, this leads to them being wary of e-commerce platforms. This leads to them not being open to try new avenues for buying such as e-platforms as new could be attributed to higher risk. Higher power-distance could also be negatively correlated with participation and e-businesses if people perceive them as business management thereby leading to reduced trust as well as lower acceptance.

\section{E-commerce, trust and social media}

As defined earlier, commercial transactions that use internet technologies to process and deliver services bring several benefits to both customers and businesses alike. Despite a plethora of opportunities and advantages e-commerce provide, there are several challenges that hinder its adoption. One of the main issues of e-commerce adoption is trust. Trust is a result of the relationship that is established by businesses with its customers. While in traditional commerce, the buyer and seller meet, e-commerce platforms do not provide this opportunity and hence not engaging with customers directly, make customers sceptical of the business. To overcome this trust barrier, businesses can leverage the power of Web 2.0 technologies such as social media platforms. Not only larger businesses, conglomerates or banking and financial services use e-commerce, this is also being adopted by small and medium enterprises extensively and studies show that in the US and Europe, these ecommerce transactions account for 38\% of the total sales (Laroche, Michel, Habibi, Mohammad Reza., Richard, Marie-Odile and Sankaranarayanan, Ramesh, 2012) 
. While businesses strive hard to expand this, studies show that there is still a lot of reluctance amongst customers to try e-commerce platforms especially in case of smaller businesses and brands.

Trust refers to the confidence that customers have or their reliance on businesses. Businesses strive hard to gain customer trust by ensuring that its resources, capabilities and strengths of implementation of specific standards of business activities are done effectively (Qu, Zhe., Wang, Youwei., Wang, Shan and Zhang, Yanhui.,2012)

- A systematic review of literature shows that enterprises strive to improve trust by implementing higher security standards and software-related mechanisms such as secure payment gateway, 2FA (2-Factor Authentication). While hardware and software security cannot be underestimated, researchers (Luo, Xueming.,2002) (Woodcock Neil, Stone Merlin, 2013)

posit that to win the trust of customers requires a more direct interaction and customer engagement in an e-commerce setting. Customer engagement and experience takes into account the quality and stability of the platform, the time and space that each transaction takes as well as avoiding any perceived risks that customers have in mind (Luo, Xueming.,2002)

Research (Zlack, T. R., 1999) shows that when social media and social networks are integrated onto e-commerce platforms, this has led to improving the user experience and also drives sales given higher engagement from customers thereby leading to higher trust. Social interactions help create an environment where positive social influence can be achieved resulting in improvement of the perceived trust in the brand (Zlack, T. R., 1999)

While several studies discuss about trust and e-commerce, trust and social media, determinants of ICT or e-commerce adoption and social media and performance of firms. However, to understand the impact of trust and social media on e-commerce requires a more holistic approach of understanding the determinants of e-commerce, social media adoption (Zlack, T. R., 1999) and how this improves trust and thus impacting the performance of the firms (Doney, Patricia M. and Joseph P. Cannon, 1997)

The following table (Table 1) analyses different studies based on different IT factors including E-commerce, social media adoption and payment technologies and data interfaces related to ecommerce. 


\begin{tabular}{|c|c|c|c|}
\hline Study & Country & IT Factor & Key Findings \\
\hline $\begin{array}{l}\text { Al-Esmail and Ashrafi, } \\
2012\end{array}$ & Qatar & ICT adoption in SMEs & $\begin{array}{l}\text { ICT adoption and } \\
\text { integrating technologies } \\
\text { such as e-commerce leads to } \\
\text { cost reduction in SMEs. }\end{array}$ \\
\hline $\begin{array}{l}\text { Yeboah-Boateng and } \\
\text { Essandoh, } 2014\end{array}$ & $\begin{array}{l}\text { Developing } \\
\text { Economies }\end{array}$ & Cloud adoption in SMEs & $\begin{array}{l}\text { Lack of trust, problems with } \\
\text { interoperability, security } \\
\text { are the key barriers to cloud } \\
\text { and other technology } \\
\text { adoption. }\end{array}$ \\
\hline Torres, 2018 & Colombia & $\begin{array}{l}\text { Adoption of e-commerce } \\
\text { technologies }\end{array}$ & $\begin{array}{l}\text { Several behavioural factors } \\
\text { such as trust lead to } \\
\text { increased adoption of e- } \\
\text { commerce technologies, } \\
\text { however, the diffusion of } \\
\text { such technologies is not } \\
\text { uniform thereby causing a } \\
\text { digital divide. }\end{array}$ \\
\hline $\begin{array}{l}\text { Leonard and Gachunga, } \\
2018\end{array}$ & Kenya & $\begin{array}{l}\text { Determinants of e- } \\
\text { commerce adoption }\end{array}$ & $\begin{array}{l}\text { State-owned enterprises in } \\
\text { Kenya are positively } \\
\text { influenced by } \\
\text { organisational, } \\
\text { technological and } \\
\text { environmental factors. E- } \\
\text { commerce adoption leads to } \\
\text { higher satisfaction in } \\
\text { customers and therefore } \\
\text { increases sales. }\end{array}$ \\
\hline $\begin{array}{l}\text { AB and Sharuddin, } \\
2018\end{array}$ & Malyasia & $\begin{array}{l}\text { E-commerce sites } \\
\text { analysis }\end{array}$ & $\begin{array}{l}\text { Customers were more likely } \\
\text { to be satisfied with sites that } \\
\text { were responsive and } \\
\text { efficient. Their loyalty } \\
\text { towards services increased } \\
\text { if they felt fulfilled. }\end{array}$ \\
\hline Santosh, 2018 & India & $\begin{array}{l}\text { Strategic management } \\
\text { and e-commerce } \\
\text { transactions of SMEs }\end{array}$ & $\begin{array}{l}\text { SMEs need to focus on } \\
\text { improving trust in e- } \\
\text { commerce to enable them to } \\
\text { expand internationally. }\end{array}$ \\
\hline Verkijika, 2018 & Cameroon & $\begin{array}{l}\text { Adoption of m- } \\
\text { commerce }\end{array}$ & $\begin{array}{l}\text { The study focuses on } \\
\text { determinants of m- } \\
\text { commerce and shows that } \\
\text { perceived risk and trust } \\
\text { along with social influence, } \\
\text { local culture and the } \\
\text { experience of using the } \\
\text { service is significant in } \\
\text { determining the adoption } \\
\text { behaviour of m-commerce } \\
\text { technologies. }\end{array}$ \\
\hline
\end{tabular}

From the table above, it is clearly evident that adoption of technologies lead to increase in customer loyalty. However, such adoptions are successful when there is a clear understanding of the businesses goals and the technology adoption is strategically aligned to the business objectives. Having good strategic focus also enables overcoming perceived risks of technology adoption. 
Based on the strategic alignment of the organisation and the reason for adopting ICT, ecommerce technologies, there are several benefits of such adoption. Table 2 below provides a list of such benefits and the studies focusing on these

\begin{tabular}{|l|l|}
\hline Factor & Studies \\
\hline eWOM (electronic Word of Mouth) Branding & Jansen et al. (2009), Bulearca and Bulearca (2010) \\
\hline $\begin{array}{l}\text { Enhancement of brand's relationship with } \\
\text { customers }\end{array}$ & $\begin{array}{l}\text { Jansen et al. (2009), Dahnil et al. (2014), Hudson } \\
\text { et al., (2015) }\end{array}$ \\
\hline Real-time information availability for customers & Vlachvei and Notta (2014) \\
\hline Networking and collaboration & Huang and Benyoucef (2013), Sigala (2017) \\
\hline $\begin{array}{l}\text { Increase customers' awareness about the } \\
\text { business and the product }\end{array}$ & $\begin{array}{l}\text { Karthikeyan and Somasundaram (2017), Tajvidi } \\
\text { et al. (2018) }\end{array}$ \\
\hline Improve business performance & $\begin{array}{l}\text { Braojos, Benitez and Llorens-Montes (2017), } \\
\text { Turban et al. (2017), }\end{array}$ \\
\hline Increase sales and profits for the business & Hajli et al. (2017), Lin, Li and Wang (2017) \\
\hline Reach out to a larger customer base & $\begin{array}{l}\text { Zhang, Guo, Hu and Liu (2017), Tuten and } \\
\text { Solomon (2017) }\end{array}$ \\
\hline $\begin{array}{l}\text { Direct interaction with customers and better } \\
\text { customer engagement }\end{array}$ & Sigala (2017), Turban et al. (2017) \\
\hline Improve trust & $\begin{array}{l}\text { Obada-Obieh and Somayaji (2017), Oliveira et al } \\
\text { (2017), Tajvidi et al. (2018) }\end{array}$ \\
\hline
\end{tabular}

While several benefits of e-commerce or social media commerce, there are several factors that researchers show impact the adoption of such technologies specifically in the KSA. These are listed in table 3 below:

\begin{tabular}{|l|l|l|}
\hline Factor & Definition & Studies \\
\hline Perceived Complexity & $\begin{array}{l}\text { Adoption of technologies in an ever-evolving environment } \\
\text { poses a huge challenge for less tech-savvy businesses or } \\
\text { Small and Medium Enterprises. There is a negative } \\
\text { correlation between technology adoption and perceived } \\
\text { complexity and hence the likelihood of SMEs adopting } \\
\text { technologies that they perceive to be complex or requiring } \\
\text { constant innovation and updates is thus low. }\end{array}$ & . \\
\hline Perceived Compatibility & $\begin{array}{l}\text { Technologies that are compatible with the existing ICT } \\
\text { framework of the organisation have a higher likelihood of } \\
\text { being adopted more easily. While most SMEs in the Kingdom } \\
\text { initially had used traditional commerce with less ICT } \\
\text { infrastructure support, they have slowly moved to adopting } \\
\text { e-commerce. However, adding social media channels would } \\
\text { require constant monitoring and this might add to the strain } \\
\text { of already having to move to e-commerce technologies }\end{array}$ & \\
\hline Resource Constraints & $\begin{array}{l}\text { One of the key challenges that hinders adoption of } \\
\text { technologies is the extent to which adopters are able to } \\
\text { observe the benefits of such technologies. There is a positive } \\
\text { correlation between observability and the use of technology. } \\
\text { In case of e-commerce, given the context of KSA, SMEs } \\
\text { already face challenges with implementation of secure } \\
\text { technologies and hence result observability takes longer. } \\
\text { This leads to further reluctance in implementing social } \\
\text { commerce into the platform as SMEs still remain sceptical } \\
\text { about the perceived benefits. }\end{array}$ & \\
\hline Observability & $\begin{array}{l} \\
\text { Perceived Risk }\end{array}$ & \\
\hline
\end{tabular}

From table 1, 2 and 3 above, it is clear that perception of risk and trust are driving factors for adoption of any technology in general and specifically m-commerce/e-commerce technologies. Trust, adoption of technologies and business performance also relies greatly on the socio- 
cultural and socio-economic dimensions and the extent to which there is infrastructure support provided for SMEs to adopt such technologies. Researchers also argue that the type of services that an entity provides and the type of entity that benefits from such services (individuals, businesses, non-profit organisations, employees, governments) also determine the transactional usage of such systems. Transactional usage of e-commerce services or any eservices also depend on the extent to which individuals believe that the entity providing the service are working in their favour (Cleary and Stokes, 2006). This trust, is thus created and enhanced when the SMEs are able to overcome the challenges to technology adoption and enable interaction with and engagement of customers. Trust can be measured by taking into account the engagement of customers and their willingness to support and cooperate with the business entity. There studies in the internet usage of KSA show that $46 \%$ of the citizens access the internet accounting for thirteen million users and it is also the fastest growing nation in terms of adoption of Twitter and social media globally (Bennett, 2013). Given the stats, it is clearly evident that the KSA's SMEs have high potential to tap the e-commerce market and engage better with customers using social media to enhance trust and also to improve financial performance. To this end, it is essential to therefore clearly estimate the link between social media platforms, trust and performance. Given the lack of studies within the specific context, this research aims to add to the literature by identifying how social media impacts trust and performance using a mixed methods approach.

\section{Summary}

This section of the paper gave an overview of the empirical context and the theoretical framework this research is based on. It ranked the aspects of Hofstede's model to highlight aspects that are distinctive and particular to Saudi Arabia. A critical review of literature to provide an understanding of the trends in e-commerce, trust and social commerce was presented which also highlighted the gaps. The next section of the paper will provide a comprehensive review of the research methodology that this paper will use.

\section{RESEARCH METHODOLOGY AND DATA}

The aim of the research is to understand the impact of social media on consumers' trust in ecommerce. The focus of this chapter is to discuss the methods and the steps that are used to for this study. A mixed method research design has been used in this paper in order to answer the research questions. This research design uses two approaches namely qualitative and quantitative methods. While qualitative approach enables the researcher get a detailed understanding of the phenomena, it is not substantial in providing a view about the issue that is being analysed (Bryman, 2003). The main issue is the lack of repeatability of the problem and limitation in terms of being able to generalise the results of findings (Saunders, 2011). In this respect quantitative research can be used to overcome these problems though it is criticised because of its independence of reality and the passivity of the researcher (Saunders, 2011). A mixed method approach, also referred to as triangulation therefore enables to explain effectively divergent issues or phenomena by providing the researcher an opportunity to both explain correlations as well as explore the topic at hand in depth.

In this research, primary data is collected through interviews and questionnaires and done in two phases between January 2018 - May 2018. Qualitative data is obtained through in-depth, semi-structured interviews that are gathered from e-business entities to understand if they are able to leverage opportunities to meet their marketing needs. This data is then thematically analysed. After the interviews with the e-businesses, they are asked to fill out a short questionnaire. In the second phase, to collect quantitative data, data is circulated via social 
media to local Saudi Arabians. 20 e-businesses (SMEs ${ }^{1}$ ) have been interviewed and participated in the survey while the survey for customers received 1044 responses.

The SMEs were selected based on the following characteristics:

1. Have less than 250 employees

2. Be registered as SMEs and located in the capital city of Riyadh given that it is the largest city in the country and KSA's commercial hub.

3. Trade on an e-commerce platform and have at least one social media (Twitter or Facebook) account.

Efforts were taken to ensure that there was industry heterogeneity in the selected SMEs. This was done to ensure that the data obtained was not biased and was also richer.

Given that data is gathered from the source directly, this increases the validity [28]. To ensure completeness, data is also gathered from secondary sources. These include published journals and other electronic resources that are used to provide statistical evidence of specific topics. Ensuring both validity and reliability of the research ensures that the study is credible [30].

When primary data is collected, sampling is a pivotal aspect that needs to be addressed in the research design (Wilmot, 2005). This is because the sampling strategy choice impacts the quality of the research and in obtaining results that are robust and unbiased (Wilmot, 2005). Though sampling is an integral aspect, it is a challenge to select participants as a representative of the entire population especially while using mixed methods approach given that when research methods are combined, there are different research designs that require different sampling strategies (Collins, Onwuegbuzie and Jaio, 2007). Given the context of the study, adoption of social media in e-commerce design for enhancing customer trust, it is essential to carefully identify potential recruits for the research. Literature suggests that the decisionmaking process lies with the business owner/manager in case of Small and Medium Enterprises and they are responsible for determining the technology implementations in their organisations (Harindranath, Dyerson and Barnes, 2008). The participants therefore are chosen based on their role in the organisation to get a better and holistic understanding of social media adoption in e-commerce businesses in Saudi Arabia. In a mixed-methods study, several techniques for sampling can be used in different stages. In the first interview-stage, the aim is to obtain holistic and comprehensive views on social media adoption as opposed to producing a sample that is statistically a representation of the population (Wilmot, 2005). Hence purposive sample is used where candidates are recruited based on the "researchspecific purpose" (Teddlie and Yu, 2007, p.77) based on their qualities (Tongco, 2007, p.147) to ensure a better insight is obtained to answer the research questions effectively (Devers and Frankel, 2000, p.264). Later, snowballing technique was used to obtain information about potential recruits for the interviews. While in the beginning, a roster of potential candidates were made using purposive sampling technique, some SME business owners were reluctant in joining or later decided to not be part of the study. Hence, the participants who took part in the interviews were asked to refer other potential candidates which is also referred to as chain referral sampling method (Edwards and Holland, 2013).

\section{ETHICAL CONSIDERATIONS}

There are several ethical concerns that researchers should take into account while collecting primary data. Researchers posit that research ethics play a significant role from the research

${ }^{1}$ SMEs are defined as businesses that have less than 250 employees 
design till the conclusion of the research (McAndrew and Jeong, 2012) and it is imperative that ethical quality standards are maintained throughout the research process (Myers and Newman, 2007). Written and informed consent has been obtained from participants and all data relating to organisation names or individual names have been anonymised. Blandford (2013) has stressed how important it is for researchers collecting primary data to obtain informed consent from the participants by explaining the need and purpose of the research and also outlining how exactly the data will be used. For SME's to participate in the interviews, a formal invitation letter outlining the research's intent was sent and this was followed up by a phone call. To reduce any uncertainties, participants were also sent a copy of the questions prior to the interview to enable them familiarise with the interview questions. Participants were also given the option to withdraw from the study at any point during the interview. The organisations were also told about the data confidentiality and all data obtained, transcribed and coded were password protected. The data was then anonymised before being analysed to ensure privacy.

\section{Qualitative study - results}

\section{ANALYSIS AND DISCUSSIONS}

Semi-structured interviews enabled collecting data from 20 SMEs in the Kingdom. The interviews enabled in-depth understanding of the factors that were perceived to influence the adoption of social media by e-commerce by the SMEs and how this has improved the performance of these SMEs. A three-step approach to analysis was being followed namely data reduction, display of data and analysis to draw conclusions (Miles and Huberman, 1994). The interviews conducted were recorded and were transcribed verbatim prior to starting the analysis. This resulted in huge amounts of textual data being obtained and the three-step process described was then followed to analyse the data.

The first step of data reduction consisted of three steps namely iterative reading, identification of themes and creating codes (Miles and Huberman, 1994). Data reduction is the process of simplifying the information obtained by providing a concise abstract to transform the data obtained. To this end, the first step was to re-read the transcripts in order to familiarise the researcher with the data and also to obtain a holistic view of the data. This helped identifying recurring themes by discarding any information that was not relevant to the topic discussed and also look at any patterns that potentially arise from the data collected (Burnard et al., 2008; Creswell, 2013). The data was sorted into themes based on the principles explained in the theoretical model of Hofstede's framework and also on the perceived ease of use. The themes and the code for each of these themes are given in table 4 below:

Table 4: Themes and codes

\begin{tabular}{|l|l|}
\hline Theme & Code \\
\hline Perceived ease of use & EOU \\
\hline Uncertainty avoidance index & UAI \\
\hline Masculinity vs Femininity & MAS \\
\hline Long-term vs short-term orientation & LTO \\
\hline Individualism vs Collectivism & IND \\
\hline
\end{tabular}

Once the themes were identified, the next step in the process was data reduction. A code was assigned to ensure that chunks of texts were tagged well and assigned to one of the themes in order to describe the data better and to show the relationship between each aspect identified and the main theme (Braun, Clarke and Terry, 2014). Larger volumes of data that have been obtained are now broken into smaller chunks. Codes are determined based on the data, theory 
or a combination of both (Cresswell, 2013). Given that the study employed hybrid approach, a combination of data and theory was used to generate the codes.

There were - initial codes that were used based on the factors identified using the theoretical framework and from the answers obtained during the interviews, these were then coded, traced as well as aligned to the main themes. For the perceived ease of use, questions were based on understanding the acceptance of social media commerce in SMEs before testing it on other cultural dimensions mentioned. These questions also acted as a baseline for other questions in the interview. The questions Uncertainty avoidance was used to understand to what extent users feel adoption of e-commerce and social commerce technologies are risky and how they feel about the regulatory framework in helping them avoid such uncertainties. Individualism vs collectivism in Hofstede's framework focuses on understanding if the society is individualistic (if personal gain takes precedence over group gains) or collectivist (if group success is perceived to be more important than individual gains). Questions here focused on understanding if social media use by SMEs were focussed on improving sales or achieve business goals or if businesses also used social media platforms for achieving collective aims (such as improvement in privacy laws, supporting group causes). To test for masculinity vs femininity, there were two questions with the first question aiming to understand if the businesses used social media to only promote the product and the brand and the second to understand the different uses of social media for the business and to understand the extent to which they engaged in promoting the customers' voices and opinions. A masculine society based on the framework is when the businesses only focus on the brand and building its market share through use of social media while a feminine society would use social media to not only improve the brand awareness but also engage with customers on different levels. To understand if SMEs were more focussed on short-term or long-term goals while implementing social media, questions focussed on the social media/e-commerce/ICT strategy of the businesses. Based on these themes, several sub-themes were then identified.

Table 5 below shows the sub-themes associated with the main themes.

\begin{tabular}{|l|l|l|}
\hline Theme & Sub-Theme & Code \\
\hline Uncertainty avoidance & Willingness to take risks & UART \\
\hline Individualism vs collectivism & Support from regulatory framework & UARF \\
\hline & Support social causes & IDSC \\
\hline & Focus on business needs & IDBN \\
\hline Masculinity vs Femininity & Competitor influence & IDCI \\
\hline & $\begin{array}{l}\text { Engage with customer at personal } \\
\text { level }\end{array}$ & MFPL \\
\hline Long-term vs Short-term & Product branding & MFPB \\
\hline & Strategy & LSS \\
\hline & Technology Advancement & LSTA \\
\hline
\end{tabular}




\section{A brief description of the 20 SMEs are provided in Table 6 below:}

\begin{tabular}{|c|c|c|c|c|c|}
\hline SME \# & Industry & $\begin{array}{l}\text { Interviewee } \\
\text { position }\end{array}$ & $\begin{array}{l}\text { Size (number } \\
\text { of employees) }\end{array}$ & $\begin{array}{l}\text { Social media } \\
\text { and other } \\
\text { technologies } \\
\text { used }\end{array}$ & $\begin{array}{l}\text { Main use for social } \\
\text { network platforms }\end{array}$ \\
\hline Org001 & Services & Owner & 120 & $\begin{array}{l}\text { Twitter, } \\
\text { Facebook }\end{array}$ & $\begin{array}{l}\text { Promote the } \\
\text { product/brand }\end{array}$ \\
\hline Org002 & Fashion & Owner & 90 & $\begin{array}{l}\text { Twitter, } \\
\text { Facebook, } \\
\text { Email, } \\
\text { Instagram }\end{array}$ & $\begin{array}{l}\text { Engage with customers, } \\
\text { branding }\end{array}$ \\
\hline Org003 & Financial Services & $\begin{array}{l}\text { Marketing } \\
\text { manager }\end{array}$ & 92 & $\begin{array}{l}\text { Facebook, } \\
\text { Email, Twitter, } \\
\text { Online Chat }\end{array}$ & $\begin{array}{l}\text { Provide information } \\
\text { about the brand }\end{array}$ \\
\hline Org004 & Fashion - Retail & $\begin{array}{l}\text { Operations } \\
\text { manager }\end{array}$ & 87 & $\begin{array}{l}\text { Twitter, } \\
\text { Instagram, } \\
\text { Google+ }\end{array}$ & $\begin{array}{l}\text { Engage with customers, } \\
\text { support social causes, } \\
\text { improve brand value }\end{array}$ \\
\hline Org005 & Wholesale & Sales Manager & 49 & $\begin{array}{l}\text { Twitter, } \\
\text { Google+, email }\end{array}$ & $\begin{array}{l}\text { Push notifications } \\
\text { about products }\end{array}$ \\
\hline Org006 & Travel and holiday & $\begin{array}{l}\text { Operations } \\
\text { manger }\end{array}$ & 59 & $\begin{array}{l}\text { Instagram, } \\
\text { Snapchat, } \\
\text { Twitter }\end{array}$ & $\begin{array}{l}\text { Push notifications } \\
\text { about products }\end{array}$ \\
\hline Org007 & $\begin{array}{l}\text { Wholesale - } \\
\text { miscellaneous } \\
\text { home } \\
\text { improvements }\end{array}$ & $\begin{array}{l}\text { Marketing } \\
\text { manager }\end{array}$ & 66 & $\begin{array}{l}\text { Snapchat, } \\
\text { Google+, } \\
\text { Twitter }\end{array}$ & $\begin{array}{l}\text { Improve brand value, } \\
\text { engage with customers }\end{array}$ \\
\hline Org008 & $\begin{array}{l}\text { Retail - home } \\
\text { improvements }\end{array}$ & Owner & 75 & Twitter, email & $\begin{array}{l}\text { Customer } \\
\text { communication reply } \\
\text { to customer queries }\end{array}$ \\
\hline Org009 & Fashion & Owner & 70 & $\begin{array}{l}\text { Twitter, } \\
\text { Instagram }\end{array}$ & $\begin{array}{l}\text { Improve brand } \\
\text { recognition, increase } \\
\text { market share }\end{array}$ \\
\hline Org010 & Services & $\begin{array}{l}\text { Operations } \\
\text { manager }\end{array}$ & 89 & $\begin{array}{l}\text { Twitter, } \\
\text { Facebook }\end{array}$ & $\begin{array}{l}\text { Push notification about } \\
\text { product }\end{array}$ \\
\hline Org011 & Household retail & Owner & 100 & $\begin{array}{l}\text { Twitter, } \\
\text { Google+ }\end{array}$ & $\begin{array}{l}\text { Push notifications for } \\
\text { product offers, } \\
\text { promotions, } \\
\text { competition }\end{array}$ \\
\hline Org012 & Fashion & $\begin{array}{l}\text { Operations } \\
\text { head }\end{array}$ & 90 & Twitter, email & $\begin{array}{l}\text { Customer } \\
\text { communication, } \\
\text { respond to customer } \\
\text { queries, competitive } \\
\text { pressure }\end{array}$ \\
\hline Org013 & Travel and holiday & Owner & 85 & Twitter & $\begin{array}{l}\text { Respond to customer } \\
\text { queries, competitive } \\
\text { pressures }\end{array}$ \\
\hline Org014 & $\begin{array}{l}\text { Groceries, Fresh } \\
\text { produce }\end{array}$ & Owner & 90 & $\begin{array}{l}\text { Twitter, } \\
\text { Google+, } \\
\text { Snapchat }\end{array}$ & $\begin{array}{l}\text { Push notifications for } \\
\text { product promotions, } \\
\text { tailored products for } \\
\text { customers, } \\
\text { recommendations } \\
\text { based on purchases, } \\
\text { competitive pressures }\end{array}$ \\
\hline Org015 & Groceries & Sales manager & 65 & $\begin{array}{l}\text { Twitter, } \\
\text { Facebook, } \\
\text { Email }\end{array}$ & $\begin{array}{l}\text { Customer satisfaction, } \\
\text { increase market share }\end{array}$ \\
\hline Org016 & $\begin{array}{l}\text { Retail all } \\
\text { household and }\end{array}$ & $\begin{array}{l}\text { Operations } \\
\text { head }\end{array}$ & 90 & $\begin{array}{l}\text { Snapchat, } \\
\text { Google+, }\end{array}$ & $\begin{array}{l}\text { Promotions, customer } \\
\text { query response }\end{array}$ \\
\hline
\end{tabular}




\begin{tabular}{|l|l|l|c|l|l|}
\hline & daily use products & & $\begin{array}{l}\text { Twitter, } \\
\text { LinkedIn }\end{array}$ & \\
\hline Org017 & $\begin{array}{l}\text { Retail all } \\
\text { household } \\
\text { products }\end{array}$ & Sales manager & 89 & $\begin{array}{l}\text { Snapchat, } \\
\text { Twitter }\end{array}$ & $\begin{array}{l}\text { Gain competitive } \\
\text { advantage }\end{array}$ \\
\hline Org018 & $\begin{array}{l}\text { Wholesale and } \\
\text { retail }\end{array}$ & Owner & 70 & $\begin{array}{l}\text { Google+, } \\
\text { Facebook, } \\
\text { Twitter }\end{array}$ & $\begin{array}{l}\text { Gain competitive } \\
\text { advantage, pressure } \\
\text { from competition }\end{array}$ \\
\hline Org019 & $\begin{array}{l}\text { Travel and travel } \\
\text { insurance }\end{array}$ & Owner & 80 & $\begin{array}{l}\text { LinkedIn, } \\
\text { Email, Twitter }\end{array}$ & $\begin{array}{l}\text { Customer queries, } \\
\text { improve sales }\end{array}$ \\
\hline Org020 & Groceries & Owner & 90 & Twitter, Email & $\begin{array}{l}\text { Push notification for } \\
\text { products }\end{array}$ \\
\hline
\end{tabular}


The table below provides the different sub-themes and whether these are supported are provided.

\begin{tabular}{|c|c|c|}
\hline Sub-theme & Discussion & Evident in investigated SMEs \\
\hline $\begin{array}{l}\text { Willingness to take } \\
\text { risks }\end{array}$ & $\begin{array}{l}\text { Supported to a moderate extent. Firms are } \\
\text { willing to take risks by implementing new } \\
\text { technologies. Some SMEs also believe that. For } \\
\text { instance, Org016 said "We use technology and } \\
\text { are willing to try something new - we were } \\
\text { one of the first SMEs to integrate social } \\
\text { commerce with e-commerce". }\end{array}$ & $\begin{array}{l}\text { Org 020, Org015, Org001, Org } \\
\text { 002, Org005, Org017, Org018, } \\
\text { Org011, Org012, Org016 }\end{array}$ \\
\hline $\begin{array}{l}\text { Support from } \\
\text { regulatory } \\
\text { framework }\end{array}$ & $\begin{array}{l}\text { Support from regulatory framework is weak } \\
\text { and one of the reasons why firms are reluctant } \\
\text { in implementing e-commerce related } \\
\text { technologies. For instance, Org003 said "I } \\
\text { could see the positive impact of technology on } \\
\text { my business but I am always afraid that if } \\
\text { something goes wrong, I cannot trust the } \\
\text { authority." }\end{array}$ & $\begin{array}{l}\text { Org 003, Org004, } \\
\text { Org006, Org008, Org009, } \\
\text { Org012, Org015, Org016, } \\
\text { Org019, Org020 }\end{array}$ \\
\hline $\begin{array}{l}\text { Support social } \\
\text { causes }\end{array}$ & $\begin{array}{l}\text { Not supported - only one organisation } \\
\text { supports social causes. Org004 for example } \\
\text { said "We pride ourselves in supporting social } \\
\text { causes. We always use popular hashtags that } \\
\text { aim at betterment of society and do that } \\
\text { alongside promoting our products.". While on } \\
\text { the other hand Org019 said "My primary focus } \\
\text { is my product, I am not interested in social } \\
\text { causes or getting into any trouble with the } \\
\text { authority." }\end{array}$ & Org004 \\
\hline $\begin{array}{l}\text { Focus on business } \\
\text { needs }\end{array}$ & $\begin{array}{l}\text { Highly supported, all business organisations } \\
\text { interviewed use social media as the primary } \\
\text { channel for communication and focussing on } \\
\text { business needs. Org } 013 \text { for instance said "My } \\
\text { brand uses social media to primarily } \\
\text { communicate with customers. Our business } \\
\text { goal is to ensure our clients are made aware of } \\
\text { our products and we communicate with them } \\
\text { and answer their queries. Social media } \\
\text { integration is more for our benefit and to suit } \\
\text { our business needs." }\end{array}$ & All \\
\hline $\begin{array}{l}\text { Competitor } \\
\text { influence }\end{array}$ & $\begin{array}{l}\text { Supported, most organisations use social } \\
\text { media only because of competitive pressures } \\
\text { in the market. For instance, Org012 said "We } \\
\text { started to integrate social media only because } \\
\text { our competitors did it. To stay ahead in the } \\
\text { race and to keep our market share, we had to } \\
\text { also integrate technology that will improve } \\
\text { customer trust." }\end{array}$ & $\begin{array}{l}\text { Org001, Org005, Org011, } \\
\text { Org012, Org013, Org015, } \\
\text { Org017, Org018 }\end{array}$ \\
\hline $\begin{array}{l}\text { Engage with } \\
\text { customer at } \\
\text { personal level }\end{array}$ & $\begin{array}{l}\text { Supported moderately with some firms using } \\
\text { social media to engage with customers, } \\
\text { however, most don't use this. Org010 for } \\
\text { example said: "Almost all e-commerce } \\
\text { businesses use social media to promote their } \\
\text { products these days. This makes us want to } \\
\text { use social media to not just convey product } \\
\text { details but to engage with customers, } \\
\text { understand their feelings, empathise with } \\
\text { their needs and make sure they are able to } \\
\text { relate to our brand better. Social media is the }\end{array}$ & $\begin{array}{l}\text { Org002, Org004, Org007, } \\
\text { Org008, Org010 }\end{array}$ \\
\hline
\end{tabular}




\begin{tabular}{|c|c|c|}
\hline & bridge that connects us." & \\
\hline Product branding & $\begin{array}{l}\text { Supported well as all brands use it for } \\
\text { promoting their products. For example, } \\
\text { Org008 said: "Our focus is promotion and } \\
\text { branding - we use our Twitter followers to } \\
\text { become our brand ambassadors. We have loyal } \\
\text { followers that help us promote the brand for } \\
\text { us. E-Word-of-Mouth is what we use Social } \\
\text { Media for." }\end{array}$ & All \\
\hline Strategy & $\begin{array}{l}\text { Not supported - while social media has been } \\
\text { adopted, this is no strategic plan for long-term } \\
\text { advancements. Org007 for example said: "We } \\
\text { implement social media to our e-commerce } \\
\text { platform only because it is in trend. All our } \\
\text { competitors use it. Our customers are there on } \\
\text { social media and we thought this is a good } \\
\text { idea. We do not have plans for the future - we } \\
\text { might or might not adopt other technologies. } \\
\text { We thought this was easy, so we went for it." }\end{array}$ & All \\
\hline $\begin{array}{l}\text { Technology } \\
\text { Advancement }\end{array}$ & $\begin{array}{l}\text { Technology advancement plan is not part of } \\
\text { the strategic objectives and hence firms are } \\
\text { not in the long-term plans. Org016 said for } \\
\text { example "We are not very much tech-savvy, } \\
\text { this was easy to use and our support person } \\
\text { said this can be done easily, so we did it. If } \\
\text { technology changes, I don't know- we don't } \\
\text { have long-term ideas yet. We haven't made } \\
\text { much changes to our website for the past } 5 \\
\text { years, they say there are more advancements } \\
\text { now, but I can't spend so much and I don't } \\
\text { have technology experts around me to tell me } \\
\text { what I should do." }\end{array}$ & All \\
\hline
\end{tabular}

From the themes, it can be understood that firms are more individualistic and are risk-taking. They do not have long-term or strategic objectives which makes it less sustainable. They are more masculine and hence the focus is just on pushing the brand and the promotions.

\section{Quantitative study - Results}

To understand the extent to which customers rely on social media before making e-purchases and estimate the extent to which engagement of SMEs with customers enhances trust and helps customers a purchase decision, questionnaires were circulated on social media over a two-month period and there were 1044 responses that were received. The survey consisted of two parts with the first part containing general questions to capture the background, age, education, gender, income levels of participants. The nominal scale was used for these questions. The second part of the questionnaire used a five-point Likert scale with three constructs and each of these constructs having 3 questions each. The range was from 1-5 with one being "completely disagree" to 5 being "completely agree".

The first set of questions aimed to capture the extent to which participants were comfortable using e-commerce technologies and social media as well as to understand whether they used social media as the primary communication channel. It also aimed to measure if purchase decisions was based on social media presence of the product. The second construct tested for individualism vs collectivism to see of social media was used as a means to stay up to date about purchase trends of others and if feedback about a product or brand on social media influenced their purchase decisions. The third construct was testing Masculinity v Femininity and the questions focussed on to what extent their purchase decisions and perception of the 
brand would change depending on the level of engagement of the firm. This was in conjunction with the interview questions to see if people preferred brands that only focussed on promoting their product or if they preferred brands that engaged with them on a more personal level. The answers obtained from the questionnaires was then coded and an ordinal level measure was used for scale questions and fixed factor questions were given a nominal scale.

To analyse the questionnaire answers, several analyses were conducted. The first one is the Confirmatory Factor analysis which was used to see if the items on the questionnaire were relevant and in line with the specific factor in question (Polit and Beck, 2008). This allows using knowledge of theory and combine it with the empirical setting to test the relationship between the observed variables statistically (Suhr, 2006. P1). To test for the relationship between the underlying construct and the variables observed, Cronbach's alpha reliability test is being used. This test will show if there is consistency internally and also if all items in a group are closely correlated. This is a function of inter-correlation among the group's items and the number of test items 2 . A value of 0.7 or higher ensures that there is internal consistency. However, when the sample is small, values between 0.6 and 0.7 are also acceptable (Moss et al., 1998; Hair et al., 2006).

The questionnaires were used to understand customer perception and this section provides the results of the surveys. There were 1044 participants with 669 males (64\%) and 375 females. The participants were within 20-55 age group with the mean age being 35.5. The participants were chosen in this age group as this was the age range of participants in employment and having disposable income to spend on products. The participants were divided into two groups of below 30s and above 30s consisting of 551 and 493 participants respectively. These were also the age group of participants where they had better access to technology. In line with Hofstede's framework and the ease of use aspect discussed earlier, the questionnaire focussed on collecting data on the following areas mentioned in table 6 below:

\begin{tabular}{|l|l|l|}
\hline Area & Question & Code \\
\hline Uncertainty avoidance & I do not make purchases online as I feel it is risky & UA1 \\
\hline & $\begin{array}{l}\text { I look at the brand's online presence and social media } \\
\text { presence before I make a purchase decision }\end{array}$ & UA2 \\
\hline & $\begin{array}{l}\text { Social media ranking and engagement of the brand is an } \\
\text { important factor that helps my purchase decisions as } \\
\text { ranking minimises risk }\end{array}$ & UA3 \\
\hline $\begin{array}{l}\text { Individualism vs } \\
\text { collectivism }\end{array}$ & $\begin{array}{l}\text { I choose brands that have many followers on social } \\
\text { media }\end{array}$ & IC1 \\
\hline & I choose brands when they support social causes & IC2 \\
\hline $\begin{array}{l}\text { Masculinity vs } \\
\text { Femininity }\end{array}$ & $\begin{array}{l}\text { I choose brands based on how the extent to which } \\
\text { customers act as brand ambassadors }\end{array}$ & IC3 \\
\hline personal level & MF1 \\
\hline & $\begin{array}{l}\text { I tend to choose brands which only engage on social } \\
\text { media to provide information about their product }\end{array}$ & MF2 \\
\hline & I choose brands where I believe they care for customers & MF3 \\
\hline
\end{tabular}

${ }^{2}$ http://www.ats.ucla.edu/stat/spss/faq/alpha.html 
From the responses, table 7 below provides the descriptive statistics for the responses:

\begin{tabular}{|l|l|l|}
\hline Factor & Mean & Standard Deviation \\
\hline UA1 & 3.5 & 1.2 \\
\hline UA2 & 4.2 & 1.1 \\
\hline UA3 & 4.6 & 0.8 \\
\hline IC1 & 3.9 & 1.0 \\
\hline IC2 & 2.4 & 2.1 \\
\hline IC3 & 3.8 & 1.0 \\
\hline MF1 & 4.2 & 1.0 \\
\hline MF2 & 3.1 & 0.4 \\
\hline MF3 & 4.2 & 0.5 \\
\hline
\end{tabular}

Based on the responses above, it is evident that except for the question on social causes the other questions have a lower standard deviation and are showing a positive trend - people use social media for improving trust and choose brands that have higher engagement with customers.

\section{Results for questionnaire}

To test if the questions measured the construct of uncertainty avoidance a Cronbach's Alpha was done and the result was 0.699 and this shows that there is a consistency in the questions and these are useful in answering the underlying construct Participants were divided into two age groups, the first group being over 30s and the second under 30s. A non-parametric test has been done by making use of the Mann-Withney U-test and the results ( $p$-value $=0.083$ ) show that there is no significant difference between the age groups in terms of answering the questions $(p>=0.05)$. Similarly, there is also no significant difference in terms of gender ( $p$ value $=0.056$ ). This means that the score is consistent across all age groups and both age groups are equally risk-averse. A T-test also shows that the answers to all independent questions do not show any difference between different age-groups or gender. A T-test is being used here given there is one independent variable (age groups and gender respectively) against one dependent variable (each of the questions independently). The T-value represents the units the means of the groups are spaced out and the test shows it can be said that the two groups are not far apart with a degree of confidence. Testing the Cronbach's Alpha for the second construct Individualism vs Collectivism had a value of 0.701 and hence questions used in the questionnaire helped answer the underlying construct. A non-parametric test using the Mann-Withney U-test shows a p-value of 0.034 and shows that there is a highly significant difference between the age groups while answering the questions. The mean for the group below 30 had a deviation of 1.18 and the over 30 s had a standard deviation of 2.13. The mean for the below 30s group was 4.2 while the over 30 s had a mean of 3.8. This shows that the younger generation had a lower individualistic attitude and favoured collective norms compared to the older generation. They supported organisations that had collectivist ideals and worked for the greater good. For the final construct, masculinity vs femininity, the Cronbach's Alpha has a value of 0.712 which shows the question consistency in answering the construct's questions. The Mann-Withney U-Test has a $\mathrm{p}=$ value of 0.028 which is significant and shows that the age groups have significant differences in answering the questions. The mean for the below 30 s age group was 3.9 while over 30 s had a mean of 2.4 with the standard deviation for both being 1.1 and 2.1 respectively. This shows that the younger generation had a lower masculinity attitude and favoured brands that appealed more to their overall needs and pushed messages that were more than just about the product. Similarly, women had lower masculinity attitude with the gender test using the Mann-Withney U-Test had a $p$ value of 0.019 and the mean for women being 3.8 and men 2.7 with a standard deviation of 0.8 and 1.3 respectively. 
Following the interviews with the SMEs, they were asked to fill out a questionnaire to capture items such as year of integrating social commerce platforms, the number of followers and revenue change since the creation of account. Then the TweetPro tool was used to obtain the number of original tweets, total tweets, retweets as well as the replies. These were then analysed. The total number of tweets for all the 20 SMEs was 459,432 . Out of the tweets, $61 \%$ approx. accounted for original tweets (280,198 tweets) with 20\% replies (91,886 tweets) and the remaining $19 \%$ accounted for by retweets $(53,228$ tweets). The twitter accounts were used by the SMEs to mainly focus on promoting the brand and post brand-related information with the average length of the tweet being 98 characters. All the accounts together had 1,234,523 followers. The analysis of these accounts showed that over the last two years, the number of users has doubled and the average tweets (including tweets, replies and retweets) was 32/day with an average tweet of 2.8 tweets per user. The top 5 organisations based on followers are provided in table 6 below3:

Table 6: Top 5 accounts based on the number of followers

\begin{tabular}{|l|l|}
\hline Account & Number of Followers \\
\hline @org10 & 291017 \\
\hline @Org4 & 270400 \\
\hline @Org2 & 236752 \\
\hline @Org18 & 216868 \\
\hline @0rg13 & 199486 \\
\hline
\end{tabular}

The top 5 accounts based on the number of tweets are summarised in Table 7 below:

Table 7: Organisations ranked based on number of tweets

\begin{tabular}{|l|l|}
\hline Organisation & Number of tweets \\
\hline @Org13 & 114343 \\
\hline @Org2 & 93452 \\
\hline @Org18 & 80915 \\
\hline @Org10 & 43993 \\
\hline @Org1 & 16729 \\
\hline
\end{tabular}

As can be seen from the table above, the top 3 organisations in terms of tweets contribute to $76 \%$ of the total tweets.

To understand if the number of tweets and followers are related to early signup, a two-tailed correlation has been performed and the results are tabulated in table 8 below:

To understand if early signup on twitter has resulted in the number of tweets and followers, a correlation has been done to check this. Table 8 shows the correlation between date created, number of followers number of original tweets.

\begin{tabular}{|l|l|l|l|}
\hline & Date created & Tweets & Followers \\
\hline Tweets & -0.034 & & \\
\hline Followers & -0.159 & $0.667\left(^{* *}\right)$ & \\
\hline
\end{tabular}

** 2-tailed correlation significant at 0.01 level

Looking at the correlation table, it is evident that while the number of followers and number of tweets have a strong correlation, there is no correlation between tweets and date of creation or

${ }^{3}$ For reasons of privacy, the names of the organisations have been anonymised 
followers and date of creation. This shows that even later adopters of technology can benefit from integrating social media in their e-commerce platforms.

Twitter communications are essentially a three-way communication and hence needs to be analysed based on the tweets, replies and retweets. The number of original tweets of organisations are given in the table 9 below:

Table 9: Top 5 organisations in terms of original tweets

\begin{tabular}{|l|l|}
\hline Organisation & Number of original tweets \\
\hline @Org2 & 60180 \\
\hline @Org10 & 54890 \\
\hline @Org1 & 48892 \\
\hline @Org13 & 34123 \\
\hline @Org18 & 23113 \\
\hline
\end{tabular}

Again, from the table of original tweets, it can be seen that the top 5 organisations account for $79 \%$ of the original tweets. This shows that these organisations are more proactive in creation of content.

Table 10 below shows the ranking of organisations in terms of the hashtags

Table 10: Top 5 organisations in terms of hashtags

\begin{tabular}{|l|l|}
\hline Organisation & Hashtag \\
\hline @Org1 & $\# 510$ \\
\hline @rg18 & $\# 432$ \\
\hline$@ 0 r g 2$ & $\# 401$ \\
\hline$@ 0 r g 10$ & $\# 339$ \\
\hline$@ 0 r g 14$ & $\# 225$ \\
\hline
\end{tabular}

From table 10, it is evident that 3 of the top organisations are well engaged compared to the others. A correlation (2-tailed) to understand the relationship between tweets, hashtags, replies and followers is shown in table 11 below:

\begin{tabular}{|l|l|l|l|l|}
\hline & Retweets & Replies & Hashtags & Followers \\
\hline Replies & 0.232 & & & \\
\hline Hashtags & -0.089 & -0.032 & & \\
\hline Followers & 0.142 & $\mathbf{0 . 6 8 5 6 ( * * )}$ & -0.032 & \\
\hline
\end{tabular}

To understand if the date of creation of twitter account, tweets, followers have an impact on the revenue of the SMEs, a two-tailed correlation has been done and the result is tabulated in table 12 below:

\begin{tabular}{|l|l|l|l|l|}
\hline & Tweets & Revenue & Date Creation & Followers \\
\hline Revenue & $\mathbf{0 . 9 0 5}(* * *)$ & & & \\
\hline Date Creation & -0.083 & -0.012 & & \\
\hline Followers & $\mathbf{0 . 5 9 0}(*)$ & $\mathbf{0 . 7 5 6}(* *)$ & -0.012 & \\
\hline
\end{tabular}

This table shows that there is a very strong correlation between the revenue, number of tweets as well as the number of followers and revenue of the SME. This clearly shows that firms that tend to engage better with the customers are able to improve trust implicitly which then increases revenue. While this is evident, the tables with the number of original tweets and followers also show that Twitter is not used as an active engagement channel and the power of social media still needs to be leveraged by the SMEs to further expand their market share as well as to earn the trust of customers. 


\section{CONCLUSION AND FUTURE WORK}

The key aim of the study was to assess to what extent Twitter (a proxy for social media commerce) plays a role in improvement of trust and thus improves revenue in e-commerce arena. From the results of the analysis, it is clear that social media marketing offers SMEs relative advantages in terms of increase in revenue given that it improves engagement with the customers and implicitly improve the trust the customers have on the brand. From the interviews the SMEs agreed that there were several advantages of using social media and the ones that were mentioned by most participants were: (i) reaching out to customers quicker and to improve communication; ii) cost savings and improve trust; iii) increase revenue. While these three were the main advantageous aspects of social media, in general the SMEs were wary of the legal and regulatory framework as the data protection and legal protection offered for e-businesses is not well developed. The society doesn't have much trust in authority and always distances itself from any authority, hence when any security threat might materialise, this leads to them having to contact authority which acts as an impediment in implementing technologies. Secondly, businesses though are willing to adopt technologies, they do so without a clear strategic plan. In most cases, these are not well-aligned with the business goals. While implementing technologies impact business performance positively in the short-run, this might not be sustainable in the long-run. Businesses need to look at technology implementation holistically and not just at immediate benefits or costs. While the interviewed SMEs all had Twitter accounts, due to lack of a vision and a strategic intent, the businesses were not effectively leveraging the power of social media to engage well with customers. This was primarily used to push information about new products or updates. This shows that while there is intention to improve customer engagement and trust, there is not much done given the masculinity aspect of Hofstede's cultural dimension - the focus is narrowed down to just product focus. From the quantitative analysis, it is very clear that the social media integration improves revenue and when there are more original tweets, which show customer engagement, then there is a significance in the number of followers and the revenue increase is highly statistically significant. However, earlier twitter account creation but lack of engagement shows that this has a negative impact though not statistically significant.

This study contributes to both literature and practice in several ways. Firstly, it shows using both qualitative and quantitative methods, how adoption of social media technology impacts trust and revenue from the point of view of the SMEs. It highlights the advantages and the impediments to such implementation given the socio-cultural context of the KSA using Hofstede's cultural model. Secondly, to holistically understand how social media impacts customers' purchase decisions and to what extent they rely on social media before deciding to purchase online. This is one of the first studies in the KSA that combines both qualitative and quantitative approach that captures both the points of view of the SMEs as well as the customers. Thirdly, by using age and gender as factors and performing the Mann-Withney tests, it showed how there is a distinction in terms of the age groups or gender concerning certain cultural dimensions/themes. This can be effectively used by the SMEs to improve the product offerings or tailor their marketing campaigns based on their target audience. It also provides the SMEs with a framework to decide on what are the most important factors to consider while implementing e-commerce/social commerce technologies.

While this study is holistic and effectively answers the research questions, the results cannot be generalised given the theoretical framework is based on cultural dimensions. It could be interesting to use this model to study SMEs in other Middle-Eastern or similar cultural societies to see how the results vary and whether firms in other similar cultures are able to perform strategically better. Similarly, another interesting area of research would be to use a 
social network methodology and analyse the Twitter accounts of the SMEs to find out if different network positions (centrality) and frequency of interaction with customers impacts financial performance. It could also be used to analyse which of the customers are the influencers of the brand and how brand awareness spreads over the network.

\section{References}

AB and Sharuddin, 2018 - AB, M.F., Sharuddin, S.H. and Rajagderan, S., 2018. E-Commerce Adoption and an Analysis of the Popular E-Commerce Business Sites in Malaysia. Journal of Internet Banking and Commerce, 23(1), pp.1-10.

Al-Esmail and Ashrafi, 2012 - Manochehri, N.N., Al-Esmail, R.A. and Ashrafi, R., 2012. Examining the impact of information and communication technologies (ICT) on enterprise practices: A preliminary perspective from Qatar. The Electronic Journal of Information Systems in Developing Countries, 51(1), pp.1-16.

Blandford, A.E., 2013. Semi-structured qualitative studies. Interaction Design Foundation.

Braojos, Benitez and Llorens-Montes (2017 - Braojos, J., Benitez, J. and Llorens-Montes, F.J., 2017. Contemporary Micro-IT Capabilities and Organizational Performance: The Role of Online Customer Engagement.

Braun, V., Clarke, V. and Terry, G., 2014. Thematic analysis. Qual Res Clin Health Psychol, 24, pp.95-114.

Bryman, A., 2003. Quantity and quality in social research. Routledge.

Bulearca, M. and Bulearca, S., 2010. Twitter: a viable marketing tool for SMEs?. Global business and management research, 2(4), p.296.

Burnard, P., Gill, P., Stewart, K., Treasure, E. and Chadwick, B., 2008. Analysing and presenting qualitative data. British dental journal, 204(8), p.429.

Chiravuri, Ananth and Nazareth, Derek. "Consumer trust in electronic commerce: an alternative framework using technology acceptance”. Electronic Commerce, 781-783, 2001.

Collins, K.M., Onwuegbuzie, A.J. and Jiao, Q.G., 2007. A mixed methods investigation of mixed methods sampling designs in social and health science research. Journal of mixed methods research, 1(3), pp.267-294.

Dahnil et al. (2014),- Dahnil, M.I., Marzuki, K.M., Langgat, J. and Fabeil, N.F., 2014. Factors influencing SMEs adoption of social media marketing. Procedia-social and behavioral sciences, 148, pp.119-126.

Dennis, Martin and Wood, 2016 - Frambach, R.T., 1993. An integrated model of organizational adoption and diffusion of innovations. European Journal of Marketing, 27(5), pp.22-41.

Devers, K.J. and Frankel, R.M., 2000. Study design in qualitative research--2: Sampling and data collection strategies. Education for health, 13(2), p.263.

Doney, Patricia M. and Joseph P. Cannon. "An examination of the nature of trust in buyer-seller relationships". Journal of Marketing, 61.2, 35-51, 1997. (Doney, Patricia M. and Joseph P. Cannon, 1997)

Edwards, R. and Holland, J., 2013. What is qualitative interviewing?. A\&C Black.

Fetters, M.D., Curry, L.A. and Creswell, J.W., 2013. Achieving integration in mixed methods designs-principles and practices. Health services research, 48(6pt2), pp.2134-2156.

Gefen, David and Detmar W. Straub. "Consumer Trust in B2c E-Commerce and the Importance of Social Presence: Experiments in E-Products and E-Services." Omega, 32.6, 407-424, 2004.

Hajli et al. (2017), Hajli, N., Sims, J., Zadeh, A.H. and Richard, M.O., 2017. A social commerce investigation of the role of trust in a social networking site on purchase intentions. Journal of Business Research, 71, pp.133-141.

Harindranath, G., Dyerson, R. and Barnes, D., 2008. ICT adoption and use in UK SMEs: a failure of initiatives?. Electronic journal of information systems evaluation, 11(2).

Huang and Benyoucef (2013), - Huang, Z. and Benyoucef, M., 2013. From e-commerce to social commerce: A close look at design features. Electronic Commerce Research and Applications, 12(4), pp.246-259.

Hudson et al., (2015) - Hudson, S., Roth, M.S., Madden, T.J. and Hudson, R., 2015. The effects of social media on emotions, brand relationship quality, and word of mouth: An empirical study of music festival attendees. Tourism Management, 47, pp.68-76.

Jansen et al. (2009), - Jansen, B.J., Zhang, M., Sobel, K. and Chowdury, A., 2009. Twitter power: Tweets as electronic word of mouth. Journal of the American society for information science and technology, 60(11), pp.2169-2188. 
Karthikeyan and Somasundaram (2017), - Karthikeyan, A., Somasundaram, K., Mahendran, M. and Yogadinesh, S., 2017, September. Bridging social media to E-Commerce: Using collaborative filtering product recommendation. In 2017 IEEE International Conference on Power, Control, Signals and Instrumentation Engineering (ICPCSI) (pp. 851-855). IEEE.

Khalidi et al., 2014 - Makki, E. and Chang, L.C., 2015. Understanding the effects of social media and mobile usage on e-commerce: an exploratory study in Saudi Arabia. International management review, 11(2), p.98.

Laroche, Michel, Habibi, Mohammad Reza., Richard, Marie-Odile and Sankaranarayanan, Ramesh. "The effects of social media based brand communities on brand community markers, value creation practices, brand trust and brand loyalty".

Leonard and Gachunga, 2018 - Leonard, L. and Gachunga, H., FACTORS INFLUENCING ADOPTION OF ELECTRONIC COMMERCE BY STATE OWNED ENTERPRISES IN KENYA: A CASE OF KENYA POWER.

Lin, Li and Wang (2017 - Lin, X., Li, Y. and Wang, X., 2017. Social commerce research: Definition, research themes and the trends. International Journal of Information Management, 37(3), pp.190-201.

Luo, Xueming. "Trust production and privacy concerns on the Internet : a framework based on relationship marketing and social exchange theory". Industrial marketing management, 3. 1, 2002. 97

Mcandrew, F.T. and Jeong, H.S., 2012. Who does what on Facebook? Age, sex, and relationship status as predictors of Facebook use. Computers in Human Behavior, 28(6), pp.2359-2365.

Miles, M.B., Huberman, A.M., Huberman, M.A. and Huberman, M., 1994. Qualitative data analysis: An expanded sourcebook. sage.

Mohd, Yasin N, and Alam S. Shah. "What Factors Influence Online Brand Trust: Evidence from Online Tickets Buyers in Malaysia." Journal of Theoretical and Applied Electronic Commerce Research. 5.3, 78-89, 2010.

Mohd, Yasin N, and Alam S. Shah. "What Factors Influence Online Brand Trust: Evidence from Online Tickets Buyers in Malaysia." Journal of Theoretical and Applied Electronic Commerce Research. 5.3, 78-89, 2010.

Myers, M.D. and Newman, M., 2007. The qualitative interview in IS research: Examining the craft. Information and organization, 17(1), pp.2-26.

Nicolaou, N. and Shane, S., "Can genetic factors influence the likelihood of engaging in entrepreneurial activity?," Journal of Business Venturing, vol. 24, pp. 1-22, 2009.

Obada-Obieh and Somayaji (2017),- Obada-Obieh, B. and Somayaji, A., 2017, October. Can I believe you?: Establishing Trust in Computer Mediated Introductions. In Proceedings of the 2017 New Security Paradigms Workshop on ZZZ (pp. 94-106). ACM.

Oliveira et al (2017), - Oliveira, T., Alhinho, M., Rita, P. and Dhillon, G., 2017. Modelling and testing consumer trust dimensions in e-commerce. Computers in Human Behavior, 71, pp.153-164.

Polit, D.F. and Beck, C.T., 2010. Generalization in quantitative and qualitative research: Myths and strategies. International journal of nursing studies, 47(11), pp.1451-1458.

Qu, Zhe., Wang, Youwei., Wang, Shan and Zhang, Yanhui. “Implications of online social activities for e-tailers' business performance”. European Journal of Marketing, Forthcoming, 1-36, 2012.

Santosh, 2018 - Kumar, V.S. and Vijayalakshmi, N., 2016. Emerging Trends in E-Commerce. ITIHAS-The Journal of Indian Management, 6(2).

Sashi, C.M. "Customer engagement, buyer-seller relationships, and social media". Management Decision, 50.2 , 253 $-272,2012.98$

Saunders, M.N., 2011. Research methods for business students, 5/e. Pearson Education India.

Sigala (2017) - Sigala, M., 2017. Collaborative commerce in tourism: implications for research and industry. Current Issues in Tourism, 20(4), pp.346-355.

Suhr, D.D., 2006. Exploratory or confirmatory factor analysis?.

Tajvidi et al. (2018) - Tajvidi, M., Wang, Y. and Hajli, N., 2018. Technological Advancement in Marketing: Cocreation of Value with Customers.

Teddlie, C. and Yu, F., 2007. Mixed methods sampling: A typology with examples. Journal of mixed methods research, 1(1), pp.77-100. 
Tongco, M.D.C., 2007. Purposive sampling as a tool for informant selection. Ethnobotany Research and applications, 5, pp.147-158.

Torres, 2018 - Pina, V., Torres, L. and Royo, S., 2010. Is e-government leading to more accountable and transparent local governments? An overall view. Financial Accountability \& Management, 26(1), pp.3-20.

Turban et al. (2017), - Turban, E., Outland, J., King, D., Lee, J.K., Liang, T.P. and Turban, D.C., 2017. Electronic commerce 2018: a managerial and social networks perspective. Springer.

Tuten and Solomon (2017) - Tuten, T.L. and Solomon, M.R., 2017. Social media marketing. Sage.

Verkijika, 2018 - Verkijika, S.F., 2018. Factors influencing the adoption of mobile commerce applications in Cameroon. Telematics and Informatics.

Vlachvei and Notta(2014) - Vlachvei, A., Notta, O., Diotallevi, F. and Marchini, A., 2014. Web Marketing Strategies in Agro Food SMEs: Evidence from Greek and Italian Wine SMEs. In E-Innovation for sustainable development of rural resources during global economic crisis(pp. 199-220). IGI Global.

Wilmot, A., 2005. Designing sampling strategies for qualitative social research: with particular reference to the Office for National Statistics' Qualitative Respondent Register. SURVEY METHODOLOGY BULLETIN-OFFICE FOR NATIONAL STATISTICS-, 56, p.53.

Woodcock Neil, Stone Merlin. “Social intelligence in customer engagement.” Journal of strategic marketing, 21. 5, 2013. (Woodcock Neil, Stone Merlin, 2013)

Yeboah-Boateng and Essandoh, 2014 - Yeboah-Boateng, E.O. and Essandoh, K.A., 2014. Factors influencing the adoption of cloud computing by small and medium enterprises in developing economies. International Journal of Emerging Science and Engineering, 2(4), pp.13-20.

Zhang, Guo, Hu and Liu (2017), - Zhang, Y., Ren, J., Liu, J., Xu, C., Guo, H. and Liu, Y., 2017. A survey on emerging computing paradigms for big data. Chinese Journal of Electronics, 26(1), pp.1-12. 